$\xi=-1$

\title{
Causes of delay in the construction phase of oil and gas projects in Malaysia
}

\author{
S Umeesh Kumar Suppramaniam ${ }^{1 *}$, Syuhaida Ismail $^{2}$, Subaashnii Suppramaniam ${ }^{3}$ \\ ${ }^{1,2}$ UTM Razak School of Engineering and Advanced Technology, Universiti Teknologi Malaysia Kuala Lumpur, \\ Jalan Sultan Yahya Petra, 54100 Kuala Lumpur, Wilayah Persekutuan Kuala Lumpur, Malaysia \\ ${ }^{3}$ Faculty of Education, Universiti Malaya, Jalan Universiti, 50603 Kuala Lumpur, Wilayah Persekutuan Kuala Lumpur, Malaysia \\ *Corresponding author E-mail: umeeshcom@yahoo.com
}

\begin{abstract}
The drop-in oil price in recent years has seen the oil and gas projects affected negatively. Thus, most Engineering, Procurement, and Construction (EPC) companies are opting to optimise the project especially in terms of mitigating delays in construction to achieve the project expectation. Delay causes threat to a project objectives in terms of time, cost and quality. It is also a crucial element in deviating from the client's expectation in terms of productivity, safety and standards. This paper aims at examining the causes of delay in the construction phase of oil and gas projects in Malaysia. A comprehensive literature review from various sources through books, conference proceedings, the internet, project management journals as well as oil and gas industry journals was made to materialise this paper. There were a few studies that related to this problem and shared a similar view with general construction projects, yet only a fraction of the factors was accepted due to the differences between the two industries. Other variances of the papers included on regional basis or on specific countries. The factors of these attributes were still accepted since it was still applicable to the oil and gas industry and there were not any major variances between countries. The paper has found that there are several significant factors that cause delays in the construction phase of oil and gas projects in Malaysia. The similarity of these delay factors can be grouped into six major groups, namely client, contractor, engineering, external, project and resources. This initial study is based purely on literature review, comparison of similar cases, cross referencing and critical judging. The causes of delay specific to the construction phase in oil and gas projects in Malaysia should be further researched with focus only in the Malaysian projects and industry players.
\end{abstract}

Keywords: Causes of Delays; Construction Phase; Oil and Gas Projects; Malaysia.

\section{Introduction}

The oil and gas industry is an important industry to the growth of the Malaysian economy and has significantly contributed to the development of the government and indirectly to the nation (1). It is a common knowledge that the oil and gas industry is divided into three main sectors, namely upstream, midstream and downstream. The oil and gas project involvement is in all the three sectors because it includes the development and handover of all types of facilities that are used in these three sectors in both onshore and offshore. The construction of these facilities is categorised as part of the construction industry in Malaysia (2).

The upstream sector of the oil and gas industry is one of the three sectors, whereas the other two being midstream, which is transportation, storage and marketing of the raw product; and downstream, which is the refining of the raw products and distribution of the by-products (3). The upstream focuses on exploration and production, where it refers to all facilities for production and stabilisation of oil and gas (4). The oil and gas projects are considered mainly the construction of these facilities for the upstream sector, such as subsea oil and gas developments, fixed platforms, semisubmersibles, Single Point Anchor Reservoir (SPARs), Tension Leg Platforms (TLPs) and Floating Production Storage and Offloading (FPSOs) $(5,6)$. However, the oil and gas projects involvement are also in the midstream and downstream sectors, namely the construction of the pipelines for transportations, storage tanks, terminal and refineries.

The construction phase is an important part of any oil and gas development both in weightage and delivery of the project, completion of this phase should be done with the least amount of delays or issues. It is evident that the success of an oil and gas project starts with detailed planning and preparation works at an earlier stage of the project (7). These planning and preparation works continue throughout the phases of the project until the final handover to continuously optimise the inputs and maximise the outputs of the project. The construction phase being the biggest phase prior to commissioning, start-up and final handover needs to be completed thoroughly or to an expected quality standard in order to ensure that it would not affect the following phases of the projects with inheritance issues (8).

\subsection{Construction Phase of Oil and Gas Projects}

Despite the oil and gas industry being segregated into three sectors to identify the main nature of the business of the key players in supporting business and management of the business itself, the construction project covers the entire oil and gas industry. Adding to this, Gonzalez et al. (3) explained further that the construction project includes overseeing from consultants in the construction and operation of projects in all areas of the industry, which includes participation in project design. The construction projects 
support the oil and gas industry strongly from the early stages of development right through operations with modification on site to the final stage in refining and transportation.

The oil and gas projects are categorised as part of the construction industry in Malaysia and it is considered a big section of the construction industry in Malaysia with two of five largest private projects being oil and gas projects in 2015/2016 according to CIDB (2016). The two projects were the Engineering, Procurement, Construction and Commissioning (EPCC) of Independent Deepwater Petroleum Terminal Phase at Pengerang, Johor and Piping and Associated Facilities (PAF) EPCC Contract at PETRONAS LNG Complex (PLC), Bintulu, Sarawak (2).

The construction project life cycle can be divided into five parts, namely conceptual design, preliminary design, detailed design, construction and testing, commissioning and handover where if classified in the term of EPC, the conceptual design, preliminary design, detailed design, are covered under the Engineering (E) and Procurement $(\mathrm{P})$ umbrella and the construction and testing, commissioning, and handover, is covered under the Construction (C) section $(9,10)$. Figure 1 shows how the typical logic flow diagram for the construction project is with sequence of the five parts of construction life cycle with the involvement of the stakeholders at the various levels as shown in figure1 by (10).

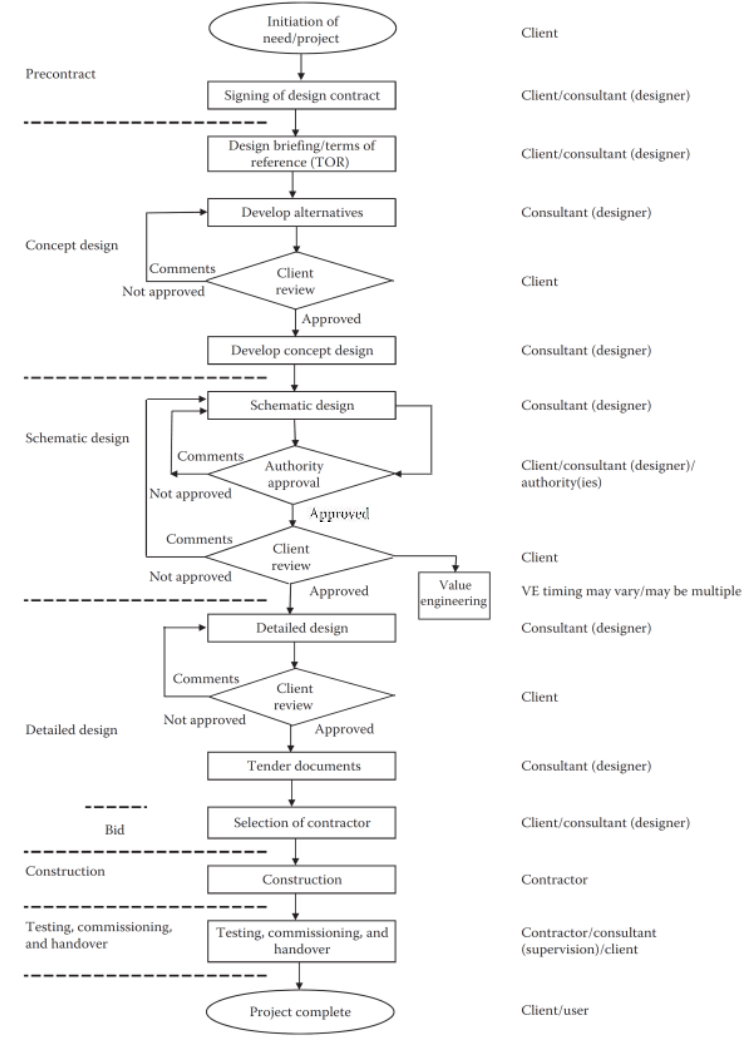

Fig. 1: Typical logic flow diagram for the construction project

\section{Literature Review}

Delay is a universal phenomenon in the construction industry, and oil and gas construction projects are not an exception. The oil and gas projects have a long construction cycle, huge financial commitments, and countless risks, which can negatively affect the completion of the project. There are various causes to the delay, where some are common problem in most projects, such as inadequate planning and ineffective project management and others, which are specific to certain projects depending on project requirements and political aspects $(11,12)$.

A report from worldwide recognised Offshore Magazine stated that nearly USD 230 billion in oil and gas projects have been deferred with main causes being subsurface challenges, government red tape, delays in agreements and financial constraints due to decline in oil price on upstream companies (11). Further, it is stat- ed that the countries that were affected are Nigeria, Kazakhstan, and Indonesia mainly and followed by Norway, Canada, Malaysia, Australia, Thailand, Ivory Coast and South Africa. It is noticed that the delay in oil and gas projects were not based on only a specific geographical location but worldwide.

For example, some of the factors for delay in oil and gas projects in Egypt were due to financial risks from poor project financing, lenient government regulations and policies, as well as out-dated project budget (13). Similarly, a project in Australia also suffered delay to financial issues due financial constraints on upstream companies from the decline in oil price (14). Other forms of delay were due to political, government policies, and inter-government policies, such as the delayed buyback issues in Iran, where the bidding process is postponed (12). This also includes the delayed start of the 1,000-kilometer Central Asia-China gas pipeline expansion, which starts in Turkmenistan, cross Uzbekistan, Tajikistan, Kyrgyzstan and ends in western China, where the project was postponed for a second time due to political constraints and issues related with inter-government policies (15).

In some cases, minor issues, such as protest from local people from surrounding area can cause a delay when the issues are not sorted at the initial period itself and elevated to the level of local authorities and later to the government intervention. This includes the Northern Gas Pipeline construction project in Australia, which is pending due to awaiting land access approvals (16) and similarly to projects in Canada (17). However, it is also highlighted that besides the issue from protestors, oil and gas projects in Canada were also suffering delays due to political issues and issues from foreign diplomacy.

Another problem that was creating a chain reaction of events is the lack of qualified and experienced personnel in projects and changes in scope of project, which elevates to having too many technical issues and forcing a cost overrun $(18,19)$. Lack of qualified and experienced personnel on site to manage change issues delays the progress with a backlog of issues that is not resolved. It is also attributed the delay in the Australia's gas projects to current oil price, causing the gas market to become very competitive. In a separate case, the delay of the project was published but the causes were not disclosed (20). The possible cause for this will be due to company policies and internal matters.

Similar to oil and gas projects worldwide, the oil and gas projects in Malaysia also experience delay due to late acceptance of agreements and financial constraints from the low oil price on upstream companies (11), pending decisions from governments (21) and changes in scope of project (22). The following section discusses the causes of the delay at the construction phase of the oil and gas projects.

\subsection{Causes of Delay at the Construction Phase of the Oil and Gas Projects}

There is a considerable similarity between the construction phase of oil and gas projects and general construction projects as discussed earlier (CIDB) (2016). Hence, the relevant literature discussing the causes of delay in the construction phase of the oil and gas projects is reviewed together with general construction projects with the intention of producing a list of causes of delay that can be surveyed through questionnaires among the oil and gas construction projects at later stages of continuation of this paper. Studies on identifying the major project management issues in oil and gas construction projects in Malaysia indicated that the three important elements which address the issues are cost, schedule and quality (23).There is a high degree of agreement among the perceptions of project stakeholders, clients, contractors and consultants on the causes of project delay, and there is no evidence to suggest that the causes of project delay differ significantly according to organisation size or organisational ownership (24). It must be noted that causes of delay at the construction phase are indifferent of organisation size and affect the three main components of successful project delivery, namely cost, schedule, and quality 
The most significant causes of delay in oil and gas project in Abu Dhabi in the EPC phase were concluded as delays in procurement and item delivery, poor selection of contractors in the planning and EPC phases (25). Some of the causes of delay identified by Ruqaishi and Bashir(24) were poor management, poor planning at the initial stages and lack of communication. It must be noted that the lack of communication was in all interfaces of the projects. Abdullah et al. (23) stated that one important aspect of delay mitigation is effective communication between the stakeholders headed by good leaders with good communication skills during interaction with team members and the customers stated

It was observed that most of the delays occurred during the Engineering, Procurement and Construction (EPC) stage of the project according to Salama et al. (26) and lack of expertise in management at earlier stages of the project affected the following phases. Similarly, another study acknowledged that poor management, poor communication, and delays in material delivery as the causes of delay for construction associated with project management, logistics and technology issues (27). Other supporting findings, such as the study conducted on construction delay of projects in peninsular Malaysia, identified that the problem of time overrun can be controlled through proper planning of work, committed leadership and management, as well as effective communication system (28). Salama et al.(26) also further criticised poor management with the concept of laying more emphasis on the bid value rather than on the contractor's competencies causing ineffective communication system and shortage in experienced manpower.

It is said that other key elements of delay mitigation include allocating sufficient resources, following the quality plan provided by the project, and project monitoring in delivering a successful project. This is supported by the deduction made by Memon et al.(29) based on the findings of the delay, which were cash flow and financial difficulties faced by contractor, poor site management and supervision, incompetent subcontractor, shortage of workers and financial difficulties of the owner.

The study by Nawi and Lee(30) categorised the causes of construction delay by communication, material, contractor, labour, project management consultant, equipment and manpower and interface management. The findings included communication amongst the multi-cultural project team, virtual communication method, split procurement team and material from overseas in the category of communication and material. This is supported by another study, which identified difficulties in integration and communication in joint venture projects (31). Other causes of delay stated by Nawi and Lee (30) in the category of project management and interface management were poor contractor performance, contractor communication, foreign workers, inexperienced project management team, poor project coordination and transportation for equipment.

The causes of delay identified in oil and gas pipeline construction projects showed that majority of the causes were due to the project and client (32). Based on the findings of the questionnaire survey, Fallahnejad (32) stated that the most of causes of delay were from unrealistic project duration, client-related materials, land expropriation, change orders, contractor selection methods, payment to contractor and obtaining permits. These were the delays that were related to the project in whole and client. Other delays identified were imported materials, change orders, suppliers and contractor's cash flow as per (32).

Another study, which concentrates on one state in peninsular Malaysia based on structured questionnaire to contractors, clients and consultants, showed that the main two factors for cause of delay were contractor and resources (33). This was further elaborated by Othman and Ismail (34) as delay in sub contractor's work, ineffective planning and scheduling of project, difficulties in financing project shortage of labours, delay in material delivery and late procurement of materials. Other causes of delay stated by Othman and Ismail (34) were slowness in process of making decision, delay in progress payment, escalation of material prices and delay in approving major changes in scope of work. These findings were categorised as client, external and engineering issues. Delay on completions of oil and gas construction projects ranges between five to twenty percent of the entire project timeframe (35) This leads to loss of revenue to the owner due to deferral of production and results in higher cost to the contractor due to fixed costs stated Simanjuntak and Mahendrawan (35). The cause of delay identified by Simanjuntak and Mahendrawan (36) are insufficient funding, inadequate experience of contractor, impractical allocation of resources, slow decision making process, poor coordination of subcontractors, incompetent site management, permit approval - local and central government and support from other sectors.

The criticality of causes of delay in construction may vary according to countries in some cases due to impact on the different delay causes or priority level of the delay cause (37). It is also evident that variance in the top three cause of delay in construction in Malaysia, Australia and Ghana, but for the purpose of this paper, these causes of delays will be combined to be researched further. The identified delays are planning and scheduling deficiencies, methods of construction, ineffective ways of monitoring and feedback, contractor's improper planning, contractor's poor site management, inadequate contractor experience, delay in payment, underestimating of project cost and underestimating the complexity of projects.

\section{Methodology}

This initial study is based purely on literature review, comparison of similar cases, cross referencing, and critical judging. Therefore, the causes of delay discussed above in the literature review are captured in Table 1 by depicting all the lists of causes of delay from the various sources. To further add value of Table 1 , this paper proposes the causes of construction delay to be categorised into six main categories, namely client, contractor, engineering, external, project and resources.

Table 1: List of causes of construction delay from literature review

\begin{tabular}{|c|c|c|}
\hline Author (Year) & Delay Causes & Group \\
\hline \multirow{5}{*}{ Salama et al. (26) } & $\begin{array}{l}\text { Delay in start of purchasing long- } \\
\text { lead items }\end{array}$ & Resources \\
\hline & $\begin{array}{l}\text { Delay in material and equipment } \\
\text { delivery }\end{array}$ & Resources \\
\hline & $\begin{array}{l}\text { Lack of experience and knowledge } \\
\text { of contractor technical staff }\end{array}$ & Contractor \\
\hline & $\begin{array}{l}\text { Poor project management by } \\
\text { contractor }\end{array}$ & Contractor \\
\hline & $\begin{array}{l}\text { Shortage of experienced and quali- } \\
\text { fied engineers }\end{array}$ & Client \\
\hline \multirow{5}{*}{ Abdullah et al. (23) } & Lack of effective communication & Project \\
\hline & Lack of effective leadership & Project \\
\hline & Insufficient resources & Resources \\
\hline & $\begin{array}{l}\text { Not adhering to the quality plan } \\
\text { provided by the project }\end{array}$ & Contractor \\
\hline & $\begin{array}{l}\text { Poor project monitoring and con- } \\
\text { trol }\end{array}$ & Contractor \\
\hline \multirow{7}{*}{$\begin{array}{l}\text { Ruqaishi and Bashir } \\
\text { (24) }\end{array}$} & $\begin{array}{l}\text { Poor site management and super- } \\
\text { vision by contractors }\end{array}$ & Contractor \\
\hline & Problems with subcontractors & Contractor \\
\hline & $\begin{array}{l}\text { Inadequate planning and schedul- } \\
\text { ing of projects by contractors }\end{array}$ & Contractor \\
\hline & $\begin{array}{l}\text { Poor management of contractor's } \\
\text { schedules }\end{array}$ & Contractor \\
\hline & Delay in delivery of materials & Resources \\
\hline & $\begin{array}{l}\text { Lack of effective communication } \\
\text { among project stakeholders }\end{array}$ & Project \\
\hline & $\begin{array}{l}\text { Poor interaction with vendors in } \\
\text { the engineering and procurement } \\
\text { stages. }\end{array}$ & Engineering \\
\hline \multirow{7}{*}{ Fallahnejad (32) } & Imported materials & Resources \\
\hline & Unrealistic project duration & Project \\
\hline & Client-related materials & Client \\
\hline & Land expropriation & Project \\
\hline & Change orders & Engineering \\
\hline & Contractor selection methods & Project \\
\hline & Payment to contractor & Client \\
\hline
\end{tabular}




\begin{tabular}{|c|c|c|}
\hline & Obtaining permits & Project \\
\hline & Suppliers & Resources \\
\hline & Contractor's cash flow & Contractor \\
\hline \multirow{5}{*}{ Memon et al. (28) } & $\begin{array}{l}\text { Cash flow and financial difficul- } \\
\text { ties faced by contractor }\end{array}$ & Contractor \\
\hline & $\begin{array}{l}\text { Poor site management and super- } \\
\text { vision }\end{array}$ & Contractor \\
\hline & Incompetent subcontractor & Contractor \\
\hline & Shortage of workers & Resources \\
\hline & Financial difficulties of the owner & Client \\
\hline \multirow{10}{*}{$\begin{array}{l}\text { Othman and } \\
\text { Ismail(34) }\end{array}$} & Delay in sub contractor's work & Contractor \\
\hline & $\begin{array}{l}\text { Ineffective planning and schedul- } \\
\text { ing of project }\end{array}$ & Contractor \\
\hline & Difficulties in financing project & Contractor \\
\hline & Shortage of labours & Resources \\
\hline & $\begin{array}{l}\text { Slowness in process of making } \\
\text { decision }\end{array}$ & Client \\
\hline & Delay in progress payment & Client \\
\hline & Delay in material delivery & Resources \\
\hline & Late procurement of materials & Resources \\
\hline & Escalation material prices & External \\
\hline & $\begin{array}{l}\text { Delay in approving major changes } \\
\text { in scope of work }\end{array}$ & Engineering \\
\hline \multirow{8}{*}{$\begin{array}{l}\text { Simanjuntak and } \\
\text { Mahendrawan (35) }\end{array}$} & Insufficient funding & Client \\
\hline & $\begin{array}{l}\text { Inadequate experience of contrac- } \\
\text { tor }\end{array}$ & Contractor \\
\hline & Impractical allocation of resources & Resources \\
\hline & Slow decision making process & Client \\
\hline & $\begin{array}{l}\text { Poor coordination of subcontrac- } \\
\text { tors }\end{array}$ & Contractor \\
\hline & Incompetent site management & Contractor \\
\hline & $\begin{array}{l}\text { Permit approval - local and central } \\
\text { government }\end{array}$ & External \\
\hline & Support from other sectors & External \\
\hline \multirow{9}{*}{ Shah (37) } & $\begin{array}{l}\text { Planning and scheduling deficien- } \\
\text { cies }\end{array}$ & Contractor \\
\hline & Methods of construction & Engineering \\
\hline & $\begin{array}{l}\text { Ineffective ways of monitoring } \\
\text { and feedback }\end{array}$ & Contractor \\
\hline & Contractor's improper planning & Contractor \\
\hline & $\begin{array}{l}\text { Contractor's poor site manage- } \\
\text { ment }\end{array}$ & Contractor \\
\hline & Inadequate contractor experience & Contractor \\
\hline & Delay in payment & Client \\
\hline & Underestimating of project cost & Project \\
\hline & $\begin{array}{l}\text { Underestimating the complexity of } \\
\text { projects }\end{array}$ & Project \\
\hline \multirow{10}{*}{ Nawi and Lee (30) } & $\begin{array}{l}\text { Communication amongst the } \\
\text { multi-cultural project team }\end{array}$ & Project \\
\hline & Virtual communication method & External \\
\hline & Split procurement team & Resources \\
\hline & Material from overseas & Resources \\
\hline & Poor contractor performance & Contractor \\
\hline & Contractor communication & Contractor \\
\hline & Foreign workers & Resources \\
\hline & $\begin{array}{l}\text { Inexperienced project management } \\
\text { team }\end{array}$ & Project \\
\hline & Poor project coordination & Contractor \\
\hline & Transportation for equipment & Project \\
\hline \multirow{5}{*}{ Rui et al. (31) } & $\begin{array}{l}\text { Project teams fail to incorporate } \\
\text { the risks in the planning phase }\end{array}$ & Project \\
\hline & Uncertainties of large projects & External \\
\hline & $\begin{array}{l}\text { Regional difference based on } \\
\text { learning experience, professional } \\
\text { standards, the local content policy, } \\
\text { the local capacity, and government } \\
\text { stability }\end{array}$ & Project \\
\hline & Higher number of JV partners & Project \\
\hline & $\begin{array}{l}\text { Poor national oil company project } \\
\text { performance due to larger varia- } \\
\text { tions }\end{array}$ & Client \\
\hline
\end{tabular}

The findings identified 74 items as the causes of construction delay. Majority the studies were on project, construction delay or project management, but only six were on oil and gas, namely Salama et al. (26), Abdullah et al. (23), Ruqaishi and Bashir (24), Fallahnejad (32), Simanjuntak and Mahendrawan (35) and Rui et al. (31) and five were of construction delay specifically in Malaysia, which are Abdullah et al. (23), Memon et al. (28), Othman and Ismail (34), Shah (37) as well as Nawi and Lee (30). The summary of the literature review is demonstrated in Table 2 .
Table 2: Literature review information

\begin{tabular}{|c|c|c|c|c|c|}
\hline Author & $\begin{array}{l}\text { Project } \\
\text { Delay }\end{array}$ & $\begin{array}{c}\text { Project } \\
\text { Man- } \\
\text { agement }\end{array}$ & $\begin{array}{c}\text { Con- } \\
\text { struc- } \\
\text { tion }\end{array}$ & $\begin{array}{l}\text { Oil } \\
\text { and } \\
\text { Gas }\end{array}$ & Country \\
\hline $\begin{array}{l}\text { Salama et } \\
\text { al. (26) }\end{array}$ & $\mathrm{X}$ & & $\mathrm{X}$ & $\mathrm{X}$ & UAE \\
\hline $\begin{array}{l}\text { Abdullah et } \\
\text { al. (23) }\end{array}$ & & $\mathrm{X}$ & & $\mathrm{X}$ & Malaysia \\
\hline $\begin{array}{l}\text { Ruqaishi } \\
\text { and Bashir } \\
\text { (24) }\end{array}$ & $\mathrm{X}$ & & X & $\mathrm{X}$ & Oman \\
\hline $\begin{array}{l}\text { Fallahnejad } \\
(32))\end{array}$ & $\mathrm{X}$ & & & $\mathrm{X}$ & Iran \\
\hline $\begin{array}{l}\text { Memon et } \\
\text { al. (28) }\end{array}$ & $\mathrm{X}$ & & $X$ & & Malaysia \\
\hline $\begin{array}{l}\text { Othman and } \\
\text { Ismail(34) }\end{array}$ & $\mathrm{X}$ & & $\mathrm{X}$ & & Malaysia \\
\hline $\begin{array}{l}\text { Simanjun- } \\
\text { tak and } \\
\text { Mahen- } \\
\text { drawan (35) }\end{array}$ & $\mathrm{X}$ & & & $X$ & Indonesia \\
\hline Shah (37) & $X$ & & $X$ & & Malaysia \\
\hline $\begin{array}{l}\text { Nawi and } \\
\text { Lee (30) }\end{array}$ & $X$ & & $\mathrm{X}$ & & Malaysia \\
\hline $\begin{array}{l}\text { Rui et al. } \\
\text { (31) }\end{array}$ & & $\mathrm{X}$ & & $\mathrm{X}$ & General \\
\hline
\end{tabular}

The findings on delay causes by Salama et al. (26) were classified in the resources, contractor and client categories. The delay in start of purchasing long-lead items and delay in material and equipment delivery were categorised under the resource group, lack of experience and knowledge of contractor technical staff and poor project management by contractor were categorised under the contractor group and finally shortage of experienced and qualified engineers grouped under the client. Abdullah et al. (23) identified the causes of delay as lack of effective communication, lack of effective leadership, insufficient resources, not adhering to the quality plan provided by the project and poor project monitoring and control. The lack of effective communication and lack of effective leadership were categorised under project, insufficient resources under resource and not adhering to the quality plan provided by the project and poor project monitoring and control under contractor.

The majority of causes of delay stated by Ruqaishi and Bashir (24) was classified in the contractor group and others were in resources, project and engineering categories. The poor site management and supervision by contractors, problems with subcontractors, inadequate planning and scheduling of projects by contractors and poor management of contractor's schedules were categorised under the contractor group. The delay in delivery of materials was grouped under resources, lack of effective communication among project stakeholders grouped under project and poor interaction with vendors in the engineering and procurement stages was categorised under engineering.

Most of the findings on delay causes found by Fallahnejad (32) were categorised under the project group. The findings were unrealistic project duration, land expropriation, contractor selection methods and obtaining permits. Other findings by Fallahnejad (11) were client related materials and payment to contractor which were classified under the clients group, imported materials and suppliers under resources, contractor's cash flow under the contractor group and finally change order management under engineering. Memon et al. (28) gave three causes of delay which were categorised under the contractor group, namely cash flow and financial difficulties faced by contractor, poor site management and supervision and incompetent subcontractor. Besides these, Memon et al. (21) stated shortage of workers which was classified under resources and financial difficulties of the owner which was grouped under client.

Two of the main categories of the finding by Othman and Ismail(34) are contractor and resources. In the contractor group the causes of delay were delay in sub contractor's work, ineffec- 
tive planning and scheduling of project and difficulties in financing project. In the resources group, the causes of delay were shortage of labours, delay in material delivery and late procurement of materials. Besides these, slowness in process of making decision and delay in progress payment were categorised under client, delay in approving major changes in scope of work under the engineering group and escalation material prices grouped as external. The findings on delay causes by Simanjuntak and Mahendrawan (35) on the other hand were classified in the client, contractor, external and resources categories. Insufficient funding and slow decision making process under client, inadequate experience of contractor, poor coordination of subcontractors and incompetent site management under contractor, permit approval by local and central government and support from other sectors as external and finally impractical allocation of resources under the resource group.

The majority of causes of delay stated by Shah (37) was classified in the contractor group and others were in client, project and engineering categories. Planning and scheduling deficiencies, ineffective ways of monitoring and feedback, contractor's improper planning, contractor's poor site management and inadequate contractor experience were categorised under the contractor group The delay in payment under client, methods of construction under engineering and underestimating of project cost and underestimating the complexity of projects under the projects group.

Three of the main categories of the finding by Nawi and Lee (30) are contractor, project and resources. In the contractor group the causes of delay were poor contractor performance, contractor communication and poor project coordination. In the project group the causes of delay were communication amongst the multicultural project team, inexperienced project management team and transportation for equipment. In the resources group the causes of delay were split procurement team, material from overseas and foreign workers. Besides these, the virtual communication method was categorised under external group.

The findings on delay causes by Rui et al. (31) were classified in the client, external and project categories. The causes of poor national oil company project performance due to larger variations grouped under client and uncertainties of large projects grouped under external. Under the category of projects the causes of delay were regional difference based on learning experience, professional standards, the local content policy, the local capacity, and government stability, failure of project teams to incorporate the risks in the planning phase and higher number of Joint Venture (JV) partners.

\section{Results and Findings}

Based on Table 1, a complete list of causes of delay at the construction phase was developed and coded as per Table 3 . The developed list has 47 items as the causes of construction delay and this will be used for the purpose of questionnaire survey in later stages of continuation of this paper.

Table 3: List of causes of delay at the construction phase DC - Delay causes

\begin{tabular}{|l|l|l|}
\hline Causes of delay at the construction phase & Group \\
\hline DC1 & Client - related materials & Client \\
\hline DC2 & Financial difficulties of the owner & Client \\
\hline DC3 & $\begin{array}{l}\text { Shortage of experienced and qualified } \\
\text { engineers }\end{array}$ & Client \\
\hline DC5 & Slowness in process of making decision & Client \\
\hline DC6 & $\begin{array}{l}\text { Client - Miscellaneous flow and financial difficulties faced } \\
\text { by contractor }\end{array}$ & Contractor \\
\hline DC7 & Contractor communication & Contractor \\
\hline DC8 & Delay in sub contractor's work & Contractor \\
\hline DC9 & Incompetent site management & Contractor \\
\hline DC10 & $\begin{array}{l}\text { Ineffective ways of monitoring and feed- } \\
\text { back }\end{array}$ & Contractor \\
\hline DC11 & Lack of experience and knowledge of & Contractor \\
\hline
\end{tabular}

\begin{tabular}{|c|c|c|}
\hline \multicolumn{2}{|c|}{ Causes of delay at the construction phase } & \multirow{2}{*}{ Group } \\
\hline & contractor technical staff & \\
\hline DC12 & $\begin{array}{l}\text { Not adhering to the quality plan provided } \\
\text { by the project }\end{array}$ & Contractor \\
\hline DC13 & Planning and scheduling deficiencies & Contractor \\
\hline DC14 & Poor contractor performance & Contractor \\
\hline DC15 & Poor coordination of subcontractors & Contractor \\
\hline DC16 & Contractor - Miscellaneous & Contractor \\
\hline DC17 & $\begin{array}{l}\text { Delay in approving major changes in } \\
\text { scope of work }\end{array}$ & Engineering \\
\hline DC18 & Methods of construction & Engineering \\
\hline DC19 & $\begin{array}{l}\text { Poor interaction with vendors in the engi- } \\
\text { neering and procurement stages }\end{array}$ & Engineering \\
\hline DC20 & Engineering - Miscellaneous & Engineering \\
\hline DC21 & Escalation material prices & External \\
\hline DC22 & $\begin{array}{l}\text { Permit approval - local and central gov- } \\
\text { ernment }\end{array}$ & External \\
\hline DC23 & Support from other sectors & External \\
\hline DC24 & Uncertainties of large projects & External \\
\hline DC25 & Virtual communication method & External \\
\hline DC26 & External - Miscellaneous & External \\
\hline DC27 & $\begin{array}{l}\text { Regional difference based on learning } \\
\text { experience, professional standards, the } \\
\text { local content policy, the local capacity, } \\
\text { and government stability }\end{array}$ & Project \\
\hline DC28 & Contractor selection methods & Project \\
\hline DC29 & $\begin{array}{l}\text { Higher number of joint-venture (JV) } \\
\text { partners }\end{array}$ & Project \\
\hline DC30 & Inexperienced project management team & Project \\
\hline DC31 & $\begin{array}{l}\text { Lack of effective communication among } \\
\text { project stakeholders }\end{array}$ & Project \\
\hline DC32 & Lack of effective leadership & Project \\
\hline DC33 & Land expropriation & Project \\
\hline DC34 & $\begin{array}{l}\text { Project teams fail to incorporate the risks } \\
\text { in the planning phase }\end{array}$ & Project \\
\hline DC35 & Transportation for equipment & Project \\
\hline DC36 & Underestimating of project cost & Project \\
\hline DC37 & $\begin{array}{l}\text { Underestimating the complexity of pro- } \\
\text { jects }\end{array}$ & Project \\
\hline DC38 & Unrealistic project duration & Project \\
\hline DC39 & Project - Miscellaneous & Project \\
\hline DC40 & Delay in material and equipment delivery & Resources \\
\hline DC41 & $\begin{array}{l}\text { Delay in start of purchasing long-lead } \\
\text { items }\end{array}$ & Resources \\
\hline DC42 & Foreign workers & Resources \\
\hline DC43 & Impractical allocation of resources & Resources \\
\hline DC44 & Shortage of labours & Resources \\
\hline DC45 & Split procurement team & Resources \\
\hline DC46 & Suppliers & Resources \\
\hline DC47 & Resources - Miscellaneous & Resources \\
\hline
\end{tabular}

The causes of delay listed in Table 3 still follow the same grouping process of the six main categories, namely client, contractor, engineering, external, project and resources. The new list of causes of delay under the category of client are client - related materials, financial difficulties of the owner, shortage of experienced and qualified engineers, slowness in process of making decision and client - miscellaneous cause of delay. The miscellaneous item was added to ensure any missed out item will be captured during the questionnaire survey. The miscellaneous item was added to all the other categories as a sub-item for the same reason.

The new list of causes of delay under the category of contractor is cash flow and financial difficulties faced by contractor, contractor communication, delay in sub contractor's work, incompetent site management, ineffective ways of monitoring and feedback, lack of experience and knowledge of contractor technical staff, not adhering to the quality plan provided by the project, planning and scheduling deficiencies, poor contractor performance, poor coordination of subcontractors and contractor - miscellaneous cause of delay. For the engineering category, the new list of causes of delay are delay in approving major changes in scope of work, methods of construction, poor interaction with vendors in the engineering and procurement stages and engineering - miscellaneous cause of 
delay. The new list of causes of delay under the external group is escalation material prices, permit approval by local and central government, support from other sectors, uncertainties of large projects, virtual communication method and external - miscellaneous cause of delay.

For the project category, the new list of causes of delay is regional difference based on learning experience, professional standards, the local content policy, the local capacity, and government stability, contractor selection methods, higher number of joint-venture (JV) partners, inexperienced project management team, lack of effective communication among project stakeholders, lack of effective leadership, land expropriation, project teams fail to incorporate the risks in the planning phase, transportation for equipment, underestimating of project cost, underestimating the complexity of projects, unrealistic project duration and project - miscellaneous cause of delay. The new list of causes of delay under the resources group is delay in material and equipment delivery, delay in start of purchasing long lead items, foreign workers, impractical allocation of resources, shortage of labours, split procurement team, suppliers and resources - miscellaneous cause of delay.

\section{Conclusion}

This initial study is based purely on literature review, comparison of similar cases, cross referencing, and critical judging. The initial findings concluded that the delay causes are primarily in six main groups, namely client, contractor, engineering, external, project and resources. The initial findings from literature review showed 10 causes of delay from the client group, 26 causes of delay from the contractor group, 4 causes of delay from the engineering group, 5 causes of delay from the external group, 15 causes of delay from the project group and 14 causes of delay from the resources group. The new list which will be used for the purpose of the questionnaire survey shows 5 causes of delay from the client group, 11 causes of delay from the contractor group, 4 causes of delay from the engineering group, 6 causes of delay from the external group, 13 causes of delay from project group and 8 causes of delay from the resources group. It should be noted that some of the findings from the literature review were similar causes of delay from different studies and hence the deduction for the new list. The new list only highlighted the unique causes of delay from the initial literature review. None of the causes of delay at the construction phase has been identified as critical at this stage of the paper and will be further reviewed with questionnaire survey. The causes of delay specific to the construction phase in oil and gas projects in Malaysia should be further researched with focus only in the Malaysian projects and industry players. The findings of this paper will help further investigate the other aspects of delay in the construction phase of oil and gas projects in Malaysia such as effects of the delay and mitigation plans for the delay.

\section{Acknowledgement}

The authors would like to express their sincere gratitude to the Ministry of Education, Universiti Teknologi Malaysia (UTM) and the Research Management Centre (RMC) of UTM for providing the financial support for this paper to be published. This paper is financed by UTM Grant for Research University (GUP) Tier 1 for research funding under Cost Centre No. Q.K130000.2540.11H09.

\section{References}

[1] Latif NAiA, Fong SK, Sandragasu L, Taufik TM. The Malaysian Oil \& Gas Industry - Challenging Times, but Fundamentals Intact. PwC Malaysia, 2016.

[2] CIDB. CONSTRUCTION INDUSTRY REVIEW AND PROSPECT 2015/2016. CIDB Malaysia, 2016.

[3] Gonzalez JLM, Taylor IP, Aguilar JC, de la Escalera LM, editors Risk and Reliability Modeling to Support Logistics Performance for
Oil and Gas Terminals. 2014 10th International Pipeline Conference; 2014: American Society of Mechanical Engineers.

[4] Garcia R, Lessard D, Singh A. Strategic partnering in oil and gas: A capabilities perspective. Energy Strategy Reviews. 2014;3:21-9.

[5] Holmager M, Dybdahl S. OffshoreBook Oil \& Gas: Offshoreenergy.dk; 2014.

[6] Devold H. Oil and gas production handbook: an introduction to oil and gas production: Lulu. com; 2013.

[7] Furlow W. Commissioning: Making the Connection Between Construction and Operations. 2014.

[8] Boschee P. Planning for Initial Startup Success. 2012.

[9] Sadeghi K. An overview of design, analysis, construction and installation of offshore petroleum platforms suitable for Cyprus oil/gas fields. GAU J Soc \& Appl Sci. 2007;2(4):1-16.

[10] Badiru AB, Osisanya SO. Project management for the oil and gas industry: a world system approach: CRC Press; 2016.

[11] Paganie D. Report finds nearly $\$ 230$ billion in oil and gas projects deferred. Offshore Magazine, 2016

[12] Tippee B. Iranian upstream bidding delayed again. Oil and Gas Journal, 2017.

[13] Akal AYBA. Financial Risks Contributing to Delay of Oil and Gas Projects in Egypt. International Journal of Accounting, Finance and Risk Management. 2016; Volume 1(Issue 1):Pages: 19-24.

[14] Klinger P. Woodside plays down Wheatstone delay. The West Australian 2016.

[15] Burke J. Central Asia-China Gas Pipeline Expansion Delayed Again. EurasiaNet.org, 2017.

[16] Beavan K. Northern Gas Pipeline construction start date delayed awaiting land access approvals. ABC Australia, 2017.

[17] Kane L. Oil and gas project delays hurting Canada's reputation, industry group says. National Observer, 2016.

[18] Gloystein H. Australia's gas projects face major delays, benefiting the US. The Sydney Morning Herald. 2017.

[19] OGN. Jizan start-up seen only by 2018. Oil \& Gas News. 2017.

[20] Atanasova S. Sohar refinery project delayed until Q1 2017. Arabian Oil and Gas, 2016.

[21] Ngui Y. Petronas May Delay Canadian LNG Project. Wall Street Journal. 2016.

[22] Sustaita M. Petronas delays PFLNG 2 amid slump. Offshore Engineer. 2016.

[23] Abdullah AA, Rahman HA, Awang MS. Identification of the major project management issues in oil and gas industry in Malaysia. International Journal of Business and Social Science. 2011;2(11).

[24] Ruqaishi M, Bashir HA. Causes of delay in construction projects in the oil and gas industry in the gulf cooperation council countries: a case study. Journal of Management in Engineering. 2013;31(3):05014017.

[25] Salama M, El Hamid MA, Keogh B, editors. Investigating the Causes of Delay within Oil and Gas Projects in the UAE. 24th Annual ARCOM Conference; 2008.

[26] Salama M, El Hamid MA, Keogh B, editors. Investigating the causes of delay within oil and gas projects in the UAE. Procs 24th Annual ARCOM Conference; 2008

[27] Nawi MNMN, Lee A. Factors influencing project delay: a case study of the vale malaysia minerals project (VMMP). International Journal of Supply Chain Management. 2016;5(4):178-84.

[28] Memon AH, Rahman IA, Akram M, Ali NM. Significant factor causing time overrun in construction projects of Peninsular Malaysia. Modern Applied Science. 2014;8(4):16.

[29] Memon AH, Abdul Rahman I, Aziz AAA. Time overrun in construction projects from the perspective of project management consultant (PMC). Journal of Surveying, Construction and Property. 2011;2(1).

[30] Nawi M, Deraman R, Hasmori M, Azimi M, Lee A. Factors influencing project delay: a case study of the vale malaysia minerals project (VMMP). Int J Sup Chain Mgt Vol. 2016;5(4):178

[31] Rui Z, Peng F, Ling K, Chang H, Chen G, Zhou X. Investigation into the performance of oil and gas projects. Journal of Natural Gas Science and Engineering. 2017;38:12-20.

[32] Fallahnejad MH. Delay causes in Iran gas pipeline projects. International Journal of project management. 2013;31(1):136-46.

[33] Othman A, Ismail S, editors. Delay in Government Project Delivery in Kedah, Malaysia. CONFERENCE PROCEEDINGS IRC-2014; 2014.

[34] Othman A, Ismail S. Delay in Government Project Delivery in Kedah, Malaysia. Recent Advances in Civil Engineering and Mechanics. 2014:248-54.

[35] Simanjuntak JT, Mahendrawan A. Factors Affecting Delay of Upstream Oil and Gas Development Projects in Indonesia: Case 
Study 2012 - 2013. 2015/10/20/. SPE: Society of Petroleum Engineers; 2015.

[36] Simanjuntak JT, Mahendrawan A. Factors Affecting Delay of Upstream Oil and Gas Development Projectors in Indonesia: Case Study 2012-2013. 2015.
[37] Shah RK. An Exploration of Causes for Delay and Cost Overruns In Construction Projects: Case Study of Australia, Malaysia \& Ghana. Journal of Advanced College of Engineering and Management. 2016;2:41-55. 